\title{
Big COVID, Red State: The Value of Over-Communication in a Public Health Crisis
}

\author{
Jen Schneider* \\ Boise State University, Boise, ID, United States
}

This Community Case Study examines the challenges of communicating about the COVID-19 crisis in a politically conservative American state, Idaho. The study presents an analysis of one local expert's communication strategies in the face of significant partisanship, threats of violence, and widespread refusal to comply with recommended public health behaviors. Findings suggest that consistent, cross-platform communication that emphasizes personalized recommendations and advice, transparency, and humility, are key strategies in a fractured information environment. However, while micro-level communication strategies are important, more must be done to help Americans regain trust in institutions, expertise, and information at a macro-level.

OPEN ACCESS

Edited by:

Ulrike Felt,

University of Vienna, Austria

Reviewed by:

Wilhelm Peekhaus,

University of Wisconsin-Milwaukee,

United States

Deborah Cox Callister, University of San Francisco, United States

*Correspondence:

Jen Schneider

jenschneider@boisestate.edu

Specialty section:

This article was submitted to Science and Environmental

Communication,

a section of the journal Frontiers in Communication

Received: 14 January 2021 Accepted: 12 May 2021

Published: 02 June 2021

Citation: Schneider J (2021) Big COVID, Red State: The Value of OverCommunication in a Public Health Crisis.

Front. Commun. 6:653665. doi: 10.3389/fcomm.2021.653665
Keywords: crisis communication, science communication, COVID-19, misinformation, conservative politics

\section{INTRODUCTION}

The COVID-19 pandemic's trajectory in the United States has created a number of opportunities to study crisis communication strategies, and especially how scientists, public health experts, and other professionals communicate during a public health crisis. The American context also allows us to analyze what constitutes effective crisis communication in a deeply polarized political environment characterized by mistrust in authority and institutions. Under the Trump administration, there was a lack of consistent pandemic leadership and management at the federal level, thus devolving authority to decision-makers at state and local levels, but without adequate support and guidance. This created a patchwork response, leading to rolling spikes in infection rates, closures of schools and businesses, and hundreds of thousands of deaths across the country. The pandemic itself has been deeply politicized; as a result, political affiliation often correlates with public health beliefs, attitudes, and behaviors (Shepherd et al., 2020). To make matters worse, social media regimes and leaders, including President Trump himself, circulated mis- and disinformation with alarming speed and in a polarizing manner (Evanega et al., 2020; Roosenbeek et al., 2020; Su, 2021).

Given this context, even skilled crisis communicators have struggled to "break through" to the public in an effective, prolonged, and non-partisan way. In fact, as communication scholars have argued, even in the best of times there is no one "public" communicators can target; rather, there are a variety of publics, and those publics may differ in their orientations toward politics, science, the media, the value of democratic norms and principles, and so on (e.g., see Metag and Schäfer, 2018). Audiences may also develop knowledge and beliefs about scientific issues based on complex media and communication "ecologies" and networks (Walter et al., 2018). Such effects are further exacerbated in a crisis, where fear and distrust are heightened. In turn, large-scale behavior change proved elusive, "COVID-fatigue" set in, and by late October 2020, the Trump White House itself admitted that it was no longer trying to actively stop the spread of the virus (McCaskill, 2020). 
Given this context, it is unsurprising that no one spokesperson or organization was able to effectively communicate across the political spectrum on the pandemic during its first year. By the end of 2020, spokespeople who were prominent early on in the pandemic had been largely sidelined by President Trump. Dr. Anthony Fauci, Director of the National Institute of Allergy and Infectious Diseases and member of the Trump Administration's Coronavirus Task Force-who has served as the Director of the National Institute of Allergy and Infectious Diseases since 1984-is considered by most public health experts to be a trusted source of information on COVID. Fauci's public profile has been fractured along political lines, however, largely because public views on the pandemic itself are partisan, and because science itself may be more or less suspect depending on one's political orientation (Barry et al., 2020; Funk et al., 2020; Mordecai and Connaughton, 2020). Fauci is trusted primarily by those on the left of the political spectrum, but is considered highly suspect to many on the right (Samuels and Chalfant, 2020; Hamel et al., 2020; Miller and Colvin, 2020; Specter 2020).

Fauci's case is instructive, and points to the many ways in which President Trump's handling of the pandemic-including his approach to crisis communication and his posture toward scientific expertise-was both unethical and counterproductive. The Fauci case also points to the challenges of attempting to engage in effective crisis communication in a deeply fractured political environment. Recommended communication practices may be less effective when audiences do not share political or scientific realities and trust in institutions is not just low but being actively undermined by bad actors. We can see this same dynamic occurring at the local level, which is the focus of this community case study.

Because most action on COVID has devolved to the state level in the absence of federal action and leadership, it is useful to explore what COVID crisis communication can look like at local scales. This case study analyzes the communication strategies of a local science communicator, Dr. David Pate, in a deeply conservative (red) state-Idaho-in order to articulate effective strategies for sustained engagement at the local level, as well as to identify the limits of those strategies under conditions of extreme political polarization. Dr. Pate has emerged as one figure (though not the only one) functioning as the local equivalent of Dr. Fauci; he provides guidance for local publics who are confused, angry, and frightened about the pandemic's management and impacts, and is a favored expert of local journalists and others seeking expertise on the pandemic. But as is the case with Dr. Fauci, it is unlikely that Pate's approaches have done much to reach those on the far-right, whose voices often dominate Idaho politics. This is because the local context and its pandemic discourses have been deeply impacted by the national response and Presidential discourse.

Below, I provide some context describing how the pandemic has unfolded in Idaho, as well as Dr. Pate's role as a public health leader and communicator. I then suggest a framework for practitioners seeking to be more effective with science and crisis communication during a public health crisis, drawing on Dr. Pate's strategies, some of which are also supported by recommendations from crisis, risk, health, and science communication literatures. I conclude the paper by discussing the limitations of focusing only on these strategies given the context of extreme hyper-partisanship and misinformation; this context limits how effective any one communicator can be. The Case Study draws on an interview I conducted with Dr. Pate, as well as analyses of public fora he has participated in, his blog, and his Twitter feed during the pandemic.

\section{Context}

Idaho is located in the Intermountain West and is a largely "rural" state-meaning most of the population of the state is located in a few urban and urbanizing areas, while the rest of the state is made up of sparsely populated public lands, Native American reservations, and land devoted to agriculture. For the last several decades the state has leaned reliably politically conservative, with the exception of a few "blue dots," the state's larger population centers. Idaho is frequently in the news for its rapid population growth, but unlike other Western states, population growth does not seem to be turning the state politically "purple." Instead, Idaho may be growing more conservative as a result of growth: it is, in fact, a destination for those leaving states like Colorado and California in search of relatively cheap real estate and more conservative politics (Lyons, 2017; Petersen, 2017).

Idaho is also known for several high-profile conflicts between the federal government and groups known for anti-government, white supremacist, and fundamentalist Christian views. A shootout between Randy Weaver and the federal government in 1992 in North Idaho is still remembered by many Republicans and Libertarians as evidence of the need for a well-armed citizenry capable of fighting federal tyranny (Geranios, 2017). Aryan compounds were rooted out in the same area after many decades of efforts by civil rights activists and government officials, but white nationalism and rightwing extremism are experiencing a resurgence there (Siegler, 2020). The Idaho Freedom Foundation (IFF), which calls itself a "free-market think tank," exerts significant influence over public discourse and decision makers each year to restrict government spending, advocate for deregulation, and boost culture wars. Groups like IFF also share ideological traits, rhetoric, and social networks with right-wing militias in the west, who in turn share much in common with white supremacist, fundamentalist, and occasionally violent domestic terror groups that have become more prominent and powerful in Idaho and nearby states (Berlet and Sunshine, 2019). Though each can claim not to be in league with the others, together they form a web of far-right influence that has had a significant impact on how the pandemic has been perceived and managed in Idaho (Frankel et al., 2020). These groups have echoed President Trump's stance on the virus, advocated against public health measures as antithetical to individual freedom, and actively worked to undermine public health experts and the Governor's efforts to coordinate action on the pandemic, often by threatening violence (Thomson-DeVeaux and Koerth, 2020). Several state officials and lawmakers-including the state's Lieutenant Governor, Janice McGeachin-have been openly sympathetic to militia members and the Idaho Freedom Foundation and have 
similarly criticized Governor Brad Little's pandemic management policies, which compared to those in other states were quite mild. For example, Little did not issue a statewide mask mandate, and spring 2020 lockdown orders were relatively brief and were lifted quickly (Armstrong, 2020).

This political context provides a particularly fecund environment in which COVID_an already rapacious and opportunistic virus-thrives. Given all of this, it should be no surprise that Idaho suffered from significant virus spikes over the course of 2020. Hospital capacity was nearly maxed out several times, and nearly 1,500 lives were lost in 2020 alone. Throughout these spikes, compliance across the state with public health guidance, such as mask-wearing, remained uneven at best, and district health boards and school districts faced tremendous pressure to act, both from those wanting stricter COVID protocols in place and from those who believed COVID was a hoax or an exaggeration. Just as the President devolved responsibility to states for managing the pandemic, so too did state officials devolve responsibility and authority to local authorities-mayors, city managers, district health boards, and school district officials. Some local officials have resigned in the face of tremendous stress, while others have faced threats to their health and safety (e.g., Corbin, 2020; Shepherd, 2020).

As the Fauci case makes clear at the national level, it can be difficult for health professionals in this environment-who typically enjoy broad public trust-to develop credibility and implement effective crisis communication messages. Given decreasing levels of trust in institutions and expertise, hyperpolarization and politicization, and the devolution and even abdication of responsibility for pandemic management, it is hard to imagine how any one organization or individual might have emerged as an authority on COVID. Individuals and organizations must operate as best they can in the face of organized interests trying to sow discord and undermining public health authority, and also in the face of rampant misand dis-information spread over social media. This paper focuses on how one individual, Dr. David Pate, managed to have meaningful public reach and influence on local and state decision-making and, to some extent, on public perception. I do not argue that Pate's strategies are universally effective; such a bar would be too high to set given the political context. But some of his approaches to crisis communication provide a roadmap for how others might aim to speak effectively to a variety of audiences, using social media and other platforms, under trying conditions.

\section{Dr. Pate's Blog and the Value of Over-Communication}

Dr. David Pate began his career as a physician in Texas. Later he obtained a law degree in addition to his medical degree and became a hospital administrator; it was this experience that eventually led to him being recruited away by the St. Luke's Health System to Boise, Idaho, where he served as a CEO for more than ten years. In fact, Pate was set to retire from that position on January 31, 2020. In preparation for retirement, he began a blog (called Dr. Pate's Blog) where he hoped to write about health care policy in ways that might continue to influence the practice of hospital administration. He also set up a Twitter account (@drpatesblog) where he planned to publicize his blog posts to a broader audience. He completed two blog posts before the pandemic became widespread news in the United States. in February. His first COVID post was published on February 2, 2020. He wrote only four more non-COVID posts after that. From April 2020 through the end of the year, all blog posts were about the pandemic, as was Pate's Twitter feed, which quickly became his primary form of public communication. At the end of 2020, Pate had more than 5,000 followers, which included a number of local journalists, who frequently tapped Pate as a resource and interviewee for stories and forums. He also published several op-eds on the pandemic, participated in two hour-long question-and-answer sessions (recorded over Zoom and shared on YouTube) sponsored by Idaho's most prominent newspaper, The Idaho Statesman, and was a frequent contributor on health forums on public radio, all while serving on the Governor's Coronavirus Working Group and serving as an independent, volunteer COVID consultant for local organizations, businesses, school boards, and hospitals. In other words, Dr. Pate was not retired for long.

I first became interested in Dr. Pate's twitter feed because, as an Idahoan, parent, and educator, I was hungry for information about the pandemic's effects here in Idaho. The advice from the federal government changed rapidly and increasingly seemed tainted by political interference from the White House. Given that void, Dr. Pate emerged as a consistent and responsive voice: he translated complicated technical information clearly, admitted when he was unsure or had been incorrect in prior interpretations, responded to Twitter followers with patience and respect, and was able to provide insight into local conditions, on the ground, in hospitals, and in the state. As a result, and seeing his increasing popularity and influence, I conducted a ninety-minute interview with him in October 2020 with a particular focus on his communication strategies. I've taken transcripts from that interview, from the two one-hour video sessions he did with the Idaho Statesman, and from his COVID-themed blog posts, and imported them into nVivo, a qualitative analysis software. I open-coded those transcripts and posts, looking for repeated themes and communication strategies. I first labeled themes with longer titles such as "responds to specific requests for advice," "admits original understanding was incorrect," and "provides deep scientific background." Eventually, I was able to group similar themes into over-arching categories, which I describe below. The naming of these categories is influenced by my reading of crisis, science, health, and risk communication literatures, which emphasize the importance of using social media during a crisis to build relationships and communicate consistently and frequently (e.g., Eriksson, 2018); fostering relationship and credibility through two-way communication connecting scientific expertise with lived experience (special issue by Fischoff and Scheufele, 2013, for extended discussion); modeling transparent reasoning and decision-making (e.g., Vaughan and Tinker, 2011); and acknowledging uncertainty and change (Seeger, 2006). 
I've also read Dr. Pate's twitter feed on a near-daily basis since March; it was Pate's Twitter feed that clued me into his work as a communicator in the first place. I follow his feed and have asked him questions on that feed myself. However, I cannot claim to have read or systematically analyzed all of Dr. Pate's tweets: there are tens of thousands from 2020, and Twitter's algorithms shape the tweets we casually see in our feeds (they are not exhaustively presented unless we seek them out specifically). A content analysis of these thousands of tweets is beyond the scope of this paper. Nonetheless, in an effort to get a fuller, more detailed snapshot of the feed, in preparation for conducing the analysis below, I used a free Tweet scraper called All My Tweets to download and read every tweet Pate posted from mid-August to mid-October (a randomly selected time frame), totaling over 3,000 tweets. I wanted to get a sense of how frequently Dr. Pate tweeted, how often he responded to followers, and of the length, tone, and content of his tweets on a daily basis. Having done this, I feel comfortable suggesting that the analysis presented below fairly represents Dr. Pate's communication strategies as a whole. I asked Dr. Pate to read a version of this manuscript as well and to offer any feedback or suggestions for revision, and he suggested none.

\section{Findings}

Pate's approach to communication during a crisis can primarily be summed up using one word: over-communication. While some leaders might pull back during a crisis in order to avoid saying the wrong thing, or to focus primarily on operations or image management, Pate obeys the opposite impulse: communicate, communicate, and communicate some more. To accomplish this, he uses several strategies that he repeats over and over again, across the many platforms he uses to reach the public. Many of these are familiar from the literature on effective crisis and science communication (see above), but reiterating them within the context of the twin crises of COVID and challenges to democratic processes and authority may be particularly useful. The four elements of Pate's informal communication strategy are.

1) consistent, frequent communication

2) pragmatic, hyper-local advice

3) modeling transparency

4) embracing humility

I discuss each briefly below and provide examples from Dr. Pate's writing, interviews, and Tweets.

\section{CONSISTENT AND FREQUENT COMMUNICATION}

Dr. Pate shows up consistently and frequently, on a near-daily basis, to his Twitter feed. This may not seem like particularly remarkable behavior, but for a volunteer science communicator, this kind of dedication and responsiveness is notable, and follows recommendations from the crisis communication literature that emphasize using social media more effectively to foster two-way communication during a crisis (Lin et al., 2016; Lovari and Bowen, 2019). Pate told me, "I think communication is really important because, number one, the vacuum will get filled. I have certainly been critical of other leaders, other organizations for not communicating enough. And when they don't communicate enough [people are going through a] scary time without information. And what people will do, in my experience, is they will fill in those gaps [with misinformation]." (David Pate, interview with the author, October 19, 2020)

Although there may not be much Pate can do to fight misinformation as an individual, in his view, when scientific and government authorities are not communicating often enough or adequately, misinformation floods in to fill the breach. Overcommunication from informed, authoritative sources can combat that effect.

Pate over-communicates on Twitter, but also across platforms. He blogs semi-frequently, but also knows that people are unlikely to read lengthy blog posts on their own. He references his blog posts on his Twitter feed in response to follower questions, but also provides brief explanations of scientific developments via threaded Tweets, a more accessible and digestible format. As was noted above, he also does frequent and lengthy media interviews, participates on expert panels, and pens op-eds. He seems to intuitively understand that the communication field is flooded with information and content-often from unreliable sources, when it comes to COVID-and that he must use a variety of outlets and approaches to reach as many publics as possible. Audiences may not be on Twitter, or on public radio, or have a newspaper subscription. But showing up across all of these venues with a consistent message that is repeated again and again increases one's chances of being heard and viewed as a dependable source of information. He has helped followers on Twitter understand complexities about topics such as positivity rates, ventilation and its impacts on transmission, hospital capacity, death certificates, district health board decisionmaking, surface transmission, and how mRNA vaccines work, to name a few. In Twitter threads he links to relevant studies, other experts, and on occasion his own writing to provide further detail. Using these layered communication techniques is another form of "over-communication"-providing multiple layers of information and repetition as reminders of what we do and do not know about the virus. To the best of my knowledge, few other authorities in Idaho followed this approach in 2020.

\section{PRAGMATIC, HYPER-LOCAL ADVICE}

The literature on risk and crisis communication suggests there are at least three important communication strategies that should be used during a crisis: "building trust, disseminating information, and fostering two-way communication" (Dalrymple et al., 2016). As we saw above, Pate's consistent and frequent communication across platforms helps him to do all three; he builds trust partly through consistent and reliable responses, and his Twitter platform and question and answer sessions allow for dialogic communication. I would add some nuance to this advice by noting that Pate regularly responds to individual, highly 
personalized questions, no matter how specific or minor they may seem. This may seem like an obvious strategy, but it has been incredibly important given the political context, which has left pandemic management primarily up to the individual as the decision-making unit. I refer to this approach as paying attention to the "hyperlocal," a phrase borrowed from journalism, referring to communication "at the unit of the individual," who is navigating a particular lived experience at the level of the banal (e.g., Harte et al., 2017). Even though scientific and medical experts coalesced relatively quickly around a core set of guidelines such as mask-wearing and social distancing, the field of information was already polluted by mis- and disinformation and political actors seeking to cast doubt on the existence of the pandemic, its origins, and appropriate responses to it. Individuals have had to step into this gap, navigating potentially lifethreatening risks, using their own heuristics and drawing on their preferred experts to guide everyday actions and behaviors.

In other words, individuals-including me-were often confused about how to behave safely given our complicated, individual contexts and lack of clear guidance from authorities. Dr. Pate stepped in to provide advice. His Twitter followers clearly feel comfortable asking him very specific questions about their own behaviors and misunderstandings, and his views on COVID-related politics and policies. Here is one example, from Twitter, which is typical of the types of backand-forth Pate invites (I've threaded together replies for readability).

"Kelley Kolpitcke (McCarten): I would like to know what plans @uidaho [University of Idaho] is planning to do with students who elect to stay put through November, December, and January. If the risk is too great for them to go home, then what? \#quagmire.

Dr. David Pate: I am glad that I am not in a position of having a college aged child or grandchild. But if I did, here is what I would do: Have a talk with them and see if our goals are aligned that they want to come home for the semester break. If so, discuss the risks and the steps they can take to reduce the risks-for the 2 weeks prior to coming home, don't go to bars, parties or other gatherings, and stay in their dorm room or apartment. Don't have guests over. Take whichever classes they can remotely, but if they have to be in class, physically distance and wear masks-at all times! If they have to fly home, take the precautions that I tweeted earlier today. When they get back to town, put them up in a hotel room. You can get together outside and 6 feet apart, but don't have them stay in your house. Do a strict quarantine. Then, if no symptoms, after 14 days, they move into the house." (Dr. David Pate, October 17, 2020).

This Twitter follower clearly has concerns about the policy being implemented by the university, which has left the follower responsible for figuring out how and whether their college-aged student can come home for the holiday. Dr. Pate provides specific guidance for how a visit could be safely managed. This is not to say his advice is the only advice, or that other experts couldn't give different advice. Rather, what is important is that Pate takes the time to spell out specific guidance in response to the question.

Another example may illustrate Pate's attention to some Idahoans' need for more specific guidance about everyday behaviors. During a videorecorded Q\&A over Zoom hosted by
The Idaho Statesman, the interviewer-journalist Audrey Dutton-asked Pate, "Well, what do you think of sports I mean, we've got schools doing indoor sports right now. Is that something that's safe?" (Pate, 2020a). The question of students being able to participate in sports in 2020, and whether their family members could cheer them on, has been a major driver of anxiety around COVID policymaking in Idaho, so much so that it became a focal point of discussions to limit the Governor's emergency powers during the 2021 legislative session. But this kind of question is also of great interest to parents who are not sure if they should allow their children to return to in-person schooling and sports participation. Here is how Pate responded:

"Well, I get that question all the time, and I have a number of follow up questions, [like] which sport? I've been asked about swimming, swimming overall is pretty safe. On the other hand, I'm having a little bit of a panic attack because I heard that Boise school district is planning to start wrestling next week. If you asked me to pick the most dangerous sport you could imagine [for COVID transmission]? I'd say wrestling. So not all sports are created equal is one thing.

And then the second thing is it's not just the sport activity. So as I said, for example, let's take swimming as the example, is swimming safe? Pretty safe. You aren't gonna be wearing a mask while you swim. You shouldn't. But you're gonna be in a swim lane, you're gonna be moving, you're not gonna be real close to others. That's pretty safe. But now, on the other hand, if you tell me when that swimmer is not swimming, that that swimmer is congregated on the side of the pool with four or five other swimmers who are not wearing mask, and they're all cheering on their teammate, well, now it's just become dangerous" (Pate, 2020a).

Again, absent clear information and systems coming from the federal and perhaps state levels, Pate steps in to provide informed suggestions for how individuals might choose to act given tremendous potential risk and uncertainty. This is the advantage of focusing on the hyper-local; it helps to build trust and responsiveness at a very personal level, and provides a sense of relief and connection at an otherwise isolating or alienating time. Furthermore, Pate models risk-informed reasoning for audiences. In this example, he articulates why swimming might be safe, but participating in the competition of swimming (clustered together, unmasked, cheering on your fellow swimmers) might not be. He has also done the same for organizations, volunteering and providing insight to a number of schools and school districts seeking feedback on their opening plans and operations.

\section{MODELING TRANSPARENCY}

In addition to providing advice, Pate is also a critic of pandemic policy and politics. When Pate critiques local school boards or district health boards, it is most frequently because they are not being transparent about their reasoning or decision-making calculus. Pate articulated at length in our interview how one of the most important lessons he learned as CEO of a health system was to first gather as much input and expertise as possible, then to 
make a decision, then to articulate why that decision was made, and then to take responsibility for that decision:

“[As a CEO] I can't make a decision that everybody's going to be happy with, but I do [want you, as an employee, to know that I] appreciate your input. I've heard it, I've valued it. And let me tell you what my decision is. And let me tell you why I made that decision. My decision was not arbitrary. [Employees] can read my reason for making the decision. They may not agree with it. They may have wanted something that I considered less strongly or more strongly, but they know how I made the decision and that it wasn't arbitrary. And that, in fact, it was thoughtful." (David Pate, interview with the author, October 19, 2020)

Pate goes on to say that a lack of transparency has plagued local decision-makers during the pandemic, contributing to significant public blowback:

"I think this is the school board problem. They get advice from the public health district and they seem to take some [of the advice] and dismiss others without a reason. And frankly, when you listen to some of these meetings that are just so painful, it's because they don't have this decision-making framework. It's not clear what criteria they're basing the decision on. They make a decision and then the next week, the decision can be internally inconsistent. And so what I've recommended to them [is], look, you don't have to do this on every decision, but on these big decisions, actually post something to your website and say, okay, this is what the board heard. These are the factors we considered. This is how we decided this factor, overruled this factor. And this is how we came to our decision. I said, I think, you know, there would probably be quite a few of the decisions I would still disagree with, but if you can tell me that you actually had a good reason for coming to your decision, I'll support it. And that is, I think, the failure" (David Pate, interview with the author, October 19, 2020).

Generally speaking, Dr. Pate could be considered a pragmatist-he doesn't believe he'll get all Idahoans to wear a mask, nor does he believe everyone will be happy with every public health decision. Furthermore, it is important to acknowledge that Dr. Pate himself is constrained by his appointment to the Governor's Coronavirus Working Group, and while he has freely critiqued both federal and local pandemic leadership, he has studiously avoided critiquing Governor Little's approach to the pandemic, even though criticism of the Governor's inaction may be warranted. He is also constrained, like many experts are, by the extreme politicization of the pandemic and political unrest in the country and in Idaho, which I described above. Nonetheless, his points about transparency and consistency are important. In a fractured information environment with low trust in authorities and institutions, having a "decision-making framework" that is clearly articulated can go some way toward easing frustration with public health and other policy decisions (Veil et al., 2011).

\section{EMBRACING HUMILITY}

Like many other scientific and emergent crises, COVID presents a challenge to communicators because conditions change so rapidly on the ground-spikes and lulls alternate, and lulls in infection rates can lead publics and decisionmakers to ease up on restrictions, which can cause spikes weeks or months later. Lag times between transmission of the disease and severe illness, hospitalization, and deaths pose problems for communicators who may be seen as exaggerating risk in advance (because they see indicators arising before the public does). Furthermore, the health system, and public health crises in general, are themselves incredibly complex, and predictions may not always be correct. For example, Dr. Pate and others predicted a spike in infections following the Christmas holidays in the United States. Which is what happened after Thanksgiving-but that spike never materialized in Idaho as expected in January (though it did elsewhere around the country); in fact, infection rates eased (Dutton, 2021). Others had predicted that the hospital system in Idaho would collapse during the November/December 2020 winter surge; though it was indeed within days of needing to enact crisis standards of care, Idaho hospitals manage to largely withstand the crisis (Dutton, 2020).

But shifting realities and projections are features of crises, not exceptions to them. In addition to articulating how transparency might work more effectively, Pate therefore also repeatedly advises that decision-makers and experts 1) acknowledge when they have gotten things wrong, 2) explain why they were wrong, and how their understanding has evolved, and 3) normalize acknowledging uncertainty and change during crises. For example, Pate often reminds readers that we don't know enough about antibody tests to be able to make robust claims about them. In an April 2020 blog post, he writes,

"Obviously, this is a fast-changing environment. We are learning more about the virus and making technological advances every day. At some point in the near future, my advice is likely to change-when we can get accurate facts and have the data to support those facts. In the meantime, let's not spend money that we are not going to get value for, and let's not imagine that these tests tell us something they don't and inadvertently put people at risk of serious, and sadly sometimes fatal, illness" (Pate, 2020b).

He also notes on Twitter periodically that he did not advise mask-wearing early on in the pandemic, but that his understanding and advice on that quickly changed as our understanding of airborne transmission developed; he is a vocal mask advocate now. On Twitter, he writes, "This is a new virus that has surprised us a number of times, and it is unfathomable that anyone has been right on everything since February about this virus. Every expert I have interacted with has admitted that [some] things they thought earlier were wrong ..." (Dr. David Pate, September 21, 2020). Acknowledging uncertainty for Pate means having humility, acknowledging expertise, but also understanding that expertise evolves. Again, these are all challenging practices to uphold when there is broad disagreement about values and what counts as evidence, truth, and expertise. But they are meaningful commitments to aspire to nonetheless. 


\section{CONCLUSION}

This Case Study highlights two seemingly paradoxical things: on one hand, many of our "best practices" for crisis and science communication hold true in the case of COVID-19 communication. The four strategies employed by Dr. Pate, described above, are echoed in much of the literature on how best to communicate during disasters, health emergencies, and other crises. Organizations, agencies, and leaders in Idaho-including many who attempted to communicate about the crisis in good faith-can learn from Dr. Pate's efforts. The Governor's office, for example, could have communicated much more frequently and across platforms about the virus and recommended health behaviors, a fact he acknowledged in an unusual moment of self-reflection in early 2021 (Dutton, 2021). Having someone show up day after day, answering questions and giving advice-paying better attention to the "hyperlocal," as it were, might have amplified the Governor's "bully pulpit" in ways that would have better served public health.

Similarly, doing more to explain decision-making that at times seemed contradictory-to Republicans and Democrats alike-might have done more to bolster public trust in state leadership. Why can bars be open, but not schools? Why do the states bordering Idaho have a mask mandate, but we don't? Why did experts say masks aren't necessary at the beginning, but they are now? Governor Little certainly wasn't the only state official to struggle to explain these inconsistencies, but doing so more forcefully and more consistently may have gone some way toward countering the more extreme reactions to COVID policies and behaviors across the spectrum. Instead, he gave periodic press conferences with the same message repeated over and over again - that Idahoans needed to take "personal responsibility" to end the pandemic. This message did little to change the minds of the far-right, and left those concerned about the pandemic feeling frustrated, angry, and helpless.

Normalizing shifting health recommendations and scientific understandings of the virus from the beginning could also have had an impact; had local hospitals done more to communicate why mask-wearing recommendations shifted early on, that also could have impacted coverage of the virus and, potentially, public behaviors. Hospitals were trusted sources of information early in the pandemic, and health workers were seen as "health heroes." Yet in Idaho, at least, they did not coordinate public information campaigns about the virus until many months after it started-perhaps worried about appearing "political"-and by then their credibility with certain publics had faded.

On the other hand, local communicators can only do so much when an issue is poisoned from early on by national actors intent on manipulating a crisis for personal gain. While health workers may have been hailed as heroes early on in the pandemic, after a state politician suggested that hospitals were falsifying COVID numbers to "make money" off the virus, and thus exaggerating its impact, the ability of healthcare spokespeople to be seen as credible by large segments of the population may have been compromised (e.g., Rogers, 2020). In such an environment, a typical "best practice" around transparency and acknowledging uncertainty may have limited success and can even backfire. In this way, the COVID crisis has much in common with the climate crisis, from a communication perspective, in that it has been deeply polarized, is characterized by disinformation efforts, and brings up a broad set of issues for people, ranging from financial to psychological to political. There are not many shared values or trusted voices that are broadly respected enough to ease these fears and concerns across the political spectrum. Add to that the fact that the pandemic itself is an evolving scientific crisis, one where we are learning more all the time about things like transmission rates and vaccine performance, and this is a perfect storm for a splintering and radicalization of responses to policy and political decisions. School boards and public health districts have already lost trust and credibility for many audiences, furthermore, and getting that trust back may prove difficult. This challenge is illustrated by the fact that the Idaho legislature considered several bills, in its 2021 session, to strip both the Governor and local public health districts of their authorities to act during a crisis, which included the ability of municipalities and counties to mandate mask-wearing, restrict gathering sizes, and accept federal emergency funding (Corbin, 2021; Norimine, 2021).

Another limitation of using Dr. Pate as a model for crisis communicators generally is that he surely has access and influence others might not have because of his professional standing and identity, which must be taken into account when we consider why he is perceived as credible in a state like Idaho. He identifies and presents as an older white man, a Christian, and a Republican, all of which gives him standing in a politically conservative and relatively culturally homogeneous state like ours. Furthermore, he is retired, which has freed him from some professional constraints other government and health officials might be limited by, and he has the time and resources to volunteer to public communication and service. He is therefore able to be a vocal advocate for COVID policymaking on social media without some of the same fears or repercussions others might face if they tried to do the same.

Still, I argue that Dr. Pate's communication strategies are worth paying close attention to, particularly because we see leaders across the country struggling to effectively communicate during this crisis at the local level-these leaders have faced a tremendous amount of responsibility, sometimes for life and death matters, and a lack of clear, consistent guidance from above. Many were under-prepared to operate in such an environment. We can take the growth and reach of Dr. Pate's Twitter feed, which is relatively broad on a local scale, his influence on local decision-makers and journalists, and his professional clout in the medical community during a time and in a place where credibility is hard to come by, as evidence that he is seen by many as an important source of public health information and guidance during COVID. His approaches may therefore prove useful to leaders in business, higher education, local and state government, and in non-profit organizations.

But it is not enough to merely train more experts to communicate like Dr. Pate. More must be done to contain and curtail mis- and disinformation, particularly across social media platforms such as YouTube and Facebook. Americans must come to terms with the influence of groups who prefer for public policy to be made (or not made) through physical threats, 
and with the collapse of trust in institutions and expertise. These macro-level challenges to effective crisis communication will likely make more micro-level efforts inconsequential if they are not meaningfully addressed moving forward.

\section{DATA AVAILABILITY STATEMENT}

The data presented in this article are either publicly available (see references) or are protected by confidentiality. Questions about data should be directed to jenschneider@boisestate.edu.

\section{REFERENCES}

Armstrong, D. (2020). States with Few Coronavirus Restrictions Are Spreading the Virus beyond Their Borders. ProPublica. Available at: https://www.propublica. org/article/states-with-few-coronavirus-restrictions-are-spreading-the-virusbeyond-their-borders. doi:10.1287/d7ebc808-cf95-43cd-b8a9-f56c6cc1858f

Barry, C., Han, H., and McGinty, B. (2020). Trust in Science and COVID-19. Johns Hopkins Bloomberg School of Public Health. Available at: https://www.jhsph. edu/covid-19/articles/trust-in-science-and-covid-19.html0.

Berlet, C., and Sunshine, S. (2019). Rural Rage: The Roots of Right-wing Populism in the United States. J. Peasant Stud. 46, 480-513. Available at: https://www. tandfonline.com/doi/full/10.1080/03066150.2019.1572603? needAccess=true. doi:10.1080/03066150.2019.1572603

Corbin, C. (2021). Legislative roundup, 2.11.21. House passes school closure bills. Idaho Education News. Available at: https://www.idahoednews. org/legislature/legislative-roundup-2-11-21-house-passes-school-closurebills/.

Corbin, C. (2020). Smylie to Resign from West Ada School Board. Idaho Education News. Available at: https://www.idahoednews.org/west-ada/smylie-to-resignfrom-west-ada-school-board/. doi:10.2172/1678839

Dalrymple, K. E., Young, R., and Tully, M. (2016). 'Facts, Not Fear:' Negotiating Uncertainty on Social media during the 2014 Ebola Crisis, Sci. Commun. 38, 4, 2016. Available at: https://journals.sagepub.com/doi/full/10.1177/1075547016655546. doi:10.1177/1075547016655546

David Pate, Dr. (2020a). Twitter post. Available at: https://twitter.com/ drpatesblog/status/1308060916945022976.

David Pate, Dr. (2020b). Twitter post. Available at: https://twitter.com/ drpatesblog/status/1317530320988590080.

Dutton, A. (2021). Idaho's COVID-19 Cases Are Dropping. Why? Everyone Has a Theory. Is Yours Right? the Idaho Statesman. Available at: https://www. eastidahonews.com/2021/02/idahos-covid-19-cases-are-dropping-why-everyonehas-a-theory-is-yours-right/. doi:10.1515/9781501754586

Dutton, A. (2020). Projections Now Say Idaho Will Avert a 'crisis Standards" Disaster over the Holidays. The Ida. Statesman. Available at: https://www. idahostatesman.com/news/coronavirus/article248064990.html.

Eriksson, M. (2018). Lessons for Crisis Communication on Social media: A Systematic Review of what Research Tells the Practice. Int. J. Strateg. Commun. 12, 5, 2018. Available at: https://www.tandfonline.com/doi/full/10. 1080/1553118X.2018.1510405. doi:10.1080/1553118x.2018.1510405

Evanega, S., Lynas, M., Adams, J., and Smolenyak, K. (2020). Coronavirus Misinformation: Quantifying Sources and Themes in the COVID-19 "infodemic". Cornell Alliance for Science. Available at: https://allianceforscience.cornell.edu/blog/ 2020/10/what-drove-the-covid-misinformation-infodemic/.

Fischhoff, B., and Scheufele, D. A. (2013). The Science of Science Communication. Proc. Natl. Acad. Sci. Available at: https://www.pnas.org/content/110/ Supplement_3/14031.short.

Frankel, J., Hoplamazian, M., and Tapper, M. (2020). Republican Leaders in Idaho Have Ties to a Rising Milia, Extremist Movement. Ida. Statesman. Available at: https://www.idahostatesman.com/news/politics-government/state-politics/ article244907762.html.

Funk, C., Kennedy, B., and Johnson, C. (2020). Trust in Medical Scientists Has Grown in U.S., but Mainly Among Democrats. Pew Res. Cent. Available at:

\section{ETHICS STATEMENT}

This study was reviewed and approved by Boise State University Office of Research Compliance. The participant provided his written informed consent to participate in this study.

\section{AUTHOR CONTRIBUTIONS}

JS gathered and analyzed all data, and wrote and edited all parts of the manuscript.

https://www.pewresearch.org/science/2020/05/21/trust-in-medical-scientistshas-grown-in-u-s-but-mainly-among-democrats/.

Geranios, NK(2017). 25 Years Later, Ruby Ridge Standoff Inspires Militia Groups. Associated Press. Available at: https://apnews.com/article/ d1c37606732147ee9cb04627facaf87a

Hamel, L., Kirzinger, A., Munana, C., and Brodie, M. (2020). KFF COVID-19 Vaccine Monitor: December 2020. https://www.kff.org/coronavirus-covid-19/ report/kff-covid-19-vaccine-monitor-december-2020/

Harte, D., Williams, A., and Turner, J. (2017). Reciprocity and the Hyperlocal Journalist. Journalism Pract. 11, 2-3. Available at: https://www.tandfonline. com/doi/full/10.1080/17512786.2016.1219963. doi:10.1080/17512786.2016 1219963

Lin, X., Spence, P. R., Sellnow, T. L., and Lachlan, K. A. (2016). Crisis Communication, Learning and Responding: Best Practices in Social media. Comput. Hum. Behav. 65, 601-605. Available at: https://www.sciencedirect. com/science/article/pii/S0747563216304137. doi:10.1016/j.chb.2016.05.080

Lovari, A., and Bowen, S. A. (2019). Social media in Disaster Communication: A Case Study of Strategies, Barriers, and Ethical Implications. J. Public Aff. 20, 1, 2019. Available at: https://onlinelibrary.wiley.com/doi/abs/10.1002/pa.1967. doi:10.1002/pa.1967

Lyons, J (2017). Don't California my Idaho? The Blue Review. https://www. boisestate.edu/bluereview/dont-california-idaho/

McCaskill, N. D. (2020). 'We're Not Going to Control the Pandemic: White House Chief s Comments Undermine Trump's Message, Politico. Available at: https:// www.politico.com/news/2020/10/25/white-house-chief-of-staff-controlpandemic432236.

Metag, J., and Schäfer, M. S. (2018). Audience Segments in Environmental and Science Communication: Recent Findings and Future Perspectives. Environ. Commun. 12, 8, 2018 . Available at: https://www.tandfonline.com/doi/full/10. 1080/17524032.2018.1521542. doi:10.1080/17524032.2018.1521542

Miller, Z., and Colvin, J. (2020). Trump attacks Dr. Anthony Fauci, says 'people are tired of hearing' him and 'all these idiots' on coronavirus. Chicago Tribune. https://www.chicagotribune.com/coronavirus/ct-nw-trump-fauci-coronavirus20201019-rofykxwrabcxdghjpa3r6tdjmu-story.html

Mordecai, M., and Connaughton, A. (2020). Public Opinion about Coronavirus Is More Politically Divided in U.S. Than in Other Advanced Economies. Pew Res. Cent. Available at: https://www.pewresearch.org/fact-tank/2020/10/28/publicopinion-about-coronavirus-is-more-politically-divided-in-u-s-than-in-otheradvanced-economies/.

Norimine, H. (2021). Here Are 8 Measures that Would Limit Gov. Little's Emergency powers as Idaho Faces COVID. Ida. Statesman. Available at: https://www.idahostatesman.com/news/politics-government/state-politics/ article248508940.html.

Pate, D. (2020a). David Pate Helps Us Better Understand What's Ahead in the Coronavirus Pandemic. YouTube. Available at: https://www.youtube.com/ watch?v=1eWlMI5qsK4.

Pate, D. (2020b). Why Idaho Employers Should Not Use Antibody Testing Today to 'get People Back to Work'. Dr. Pate's Blog. Available at: https://drpatesblog. com/2020/04/21/why-idaho-employers-should-not-use-antibody-testingtoday-to-get-people-back-to-work/.

Petersen, A. H. (2017). Welcome to Idaho, Now Go home. Buzzfeed News. Available at: https://www.buzzfeednews.com/article/annehelenpetersen/ wackadoodles-north-idaho. 
Roozenbeek, J., Schneider, C. R., Dryhurst, S., Kerr, J., Freeman, A. L. J., Recchia, G., et al. (2020). Susceptibility to Misinformation about COVID-19 Around the World. R. Soc. Open Sci. 7, 201199. doi:10.1098/rsos.201199

Samuels, B., and Chalfant, M. (2020). Fauci at center of conservative storm. The Hill. Available at: https://thehill.com/homenews/administration/492525-fauciat-center-of-conservative-storm

Seeger, M. W. (2006). Best Practices in Crisis Communication: An Expert Panel Process. J. Appl. Commun. Res. 34, 3, 2006. Available at: https://nca.tandfonline. com/doi/full/10.1080/00909880600769944\#.YEz0EeZlBao.

Shepherd, H., MacKendrick, N., and Mora, G. C. (2020). Pandemic Politics: Political Worldviews and COVID-19 Beliefs and Practices in an Unsettled Time. Socius: Sociological Res. a Dynamic World 5. 2020. Available at: https:// journals.sagepub.com/doi/full/10.1177/2378023120972575.

Shepherd, K. (2020). An Idaho Official Left a Meeting in Tears as Anti-maskers Swarmed Her home. The Wash. Post. Available at: https://www. washingtonpost.com/nation/2020/12/09/idaho-coronavirus-protest-homes/.

Siegler, K. (2020). Are paramilitary extremists being normalized? Look to Idaho for answers. National Public Radio. https://www.npr.org/2020/10/17/924461164/ are-paramilitary-extremists-being-normalized-look-to-idaho-for-answers

Specter, M. (2020). How Anthony Fauci Became America's Doctor. The New Yorker. https://www.newyorker.com/magazine/2020/04/20/how-anthony-faucibecame-americas-doctor

Su, Y. (2020). It Doesn't Take a Village to Fall for Misinformation: Social media Use, Discussion Heterogeneity Preference, Worry of the Virus, faith in Scientists, and COVID-19-Related Misinformation Beliefs. Telematics Inform. 58. 2020. Available at: https://www.sciencedirect.com/science/ article/pii/S0736585320302069.
Thomson-DeVeaux, A., and Koerth, M. (2020). How Trump and COVID-19 Have Reshaped the Modern Militia Movement. FiveThirtyEight. Available at: https:// fivethirtyeight.com/features/how-trump-and-covid-19-have-reshaped-themodern-militia-movement/.

Vaughn, E., and Tinker, T. (2011). Effective Health Risk Communication about Pandemic Influenza for Vulnerable Populations. Am. J. Public Health. Available at: https://ajph.aphapublications.org/doi/full/10.2105/AJPH.2009.162537.

Veil, S. R., Buehner, T., and Palenchar, M. J. (2011). A Work-In-Process Literature Review: Incorporating Social media in Risk and Crisis Communication. J. Contingencies Crisis Manag. 19, 2, 2011 . Available at: https:// onlinelibrary.wiley.com/doi/full/10.1111/j.1468-5973.2011.00639.x. doi:10. 1111/j.1468-5973.2011.00639.x

Walter, N., Ball-Rokeach, S. J., Xu, Y., and Broad, G. M. (2018). Communication Ecologies: Analyzing Adoption of False Beliefs in an Information-Rich Environment. Sci. Commun. 40, 5, 2018. Available at: https://journals.sagepub. com/doi/full/10.1177/1075547018793427. doi:10.1177/1075547018793427

Conflict of Interest: The authors declare that the research was conducted in the absence of any commercial or financial relationships that could be construed as a potential conflict of interest.

Copyright $\odot 2021$ Schneider. This is an open-access article distributed under the terms of the Creative Commons Attribution License (CC BY). The use, distribution or reproduction in other forums is permitted, provided the original author $(s)$ and the copyright owner(s) are credited and that the original publication in this journal is cited, in accordance with accepted academic practice. No use, distribution or reproduction is permitted which does not comply with these terms. 